\title{
AN EXPLORATORY STUDY OF MOTIVATIONS DRIVING Corporate Investment in Voluntary Climate Change Mitigation in SoUTH AFrica
}

\author{
Michelle Reyers \& Daan Gouws \\ Department of Financial Management, University of Pretoria
}

James Blignaut

Department of Economics, University of Pretoria

Accepted September 2010

\begin{abstract}
This study investigates factors driving investment in voluntary climate change mitigation among a selection of listed corporations in South Africa. Based on a review of the literature, a proposed conceptual framework is developed and empirically tested using case studies. A qualitative analysis of the data reveals three key motivational drivers: legitimacy, the financial business case and moral responsibility. In addition, a number of sub-drivers are identified which provide insights for engagement with companies in developing South Africa's response to climate change.
\end{abstract}

Key words: corporate sustainability, climate change strategies, investment

JEL M14, Q54, 56

1

\section{Introduction}

Climate change is acknowledged as one of the greatest threats facing humanity in the $21^{\text {st }}$ century (Watkins, 2007). While global warming will have worldwide consequences, the African continent is most vulnerable to the impact of climate change due to the climate sensitivity of its major economic sectors coupled with current developmental challenges (Boko et al., 2007). Africa emits a very small portion of total greenhouse gas (GHG) emissions, however, South Africa has the highest emissions on the continent contributing approximately $1 \%$ of global GHG emissions in 2004 (Scenario Building Team, 2007). This places it among the top 20 GHG emitters worldwide (Baumert, Herzog, \& Pershing, 2005). Due to South Africa's role as an economic powerhouse on the continent, and its investment in, and trade with, the rest of Africa (Grobbelaar, 2008), it is uniquely placed to adopt a proactive stance to climate change mitigation. Already there is acknowledgement of the role South Africa should play in terms of support and participation in broader African climate change initiatives (Blignaut, Mabugu \& Chitiga-Mabugu, 2005; Department of Environmental Affairs and Tourism, 2009; Van Heerden et al., 2006). In addition, the country is in the process of developing its policy response to climate change, scheduled for publication towards the end of 2010 (Department of Environmental Affairs and Tourism, 2009).

Due to its status as a developing country, South Africa is not subject to mandatory emission reduction targets in terms of the Kyoto Protocol. Despite the lack of regulatory imperatives to dictate climate change action, certain South African companies have voluntarily introduced climate change mitigation strategies, however others have yet to take action. Understanding the motivations driving such action or inaction could provide insights regarding how best to engage companies to ensure a sustainable future.

The purpose of this study is to determine the motivation for South African corporate 
investment in voluntary climate change mitigation projects. The research questions that this study aims to address are:

1) What motivates South African companies to invest in sustainability initiatives related to voluntary climate change mitigation?

2) Do the above-mentioned motivations differ between companies perceived to be more responsible and accountable from a sustainability perspective compared with those who are perceived to be less responsible?

This paper has four parts. First it reviews the literature related to corporate motivations for sustainability and climate change action with the aim of developing a proposed conceptual framework. Second it outlines the method selected to empirically test the framework in a South African context. Thereafter results of the empirical study are discussed. The paper concludes with an overview of the implications of the findings and highlights some areas for further research.

\section{2}

\section{Background and a preliminary model}

The field of corporate sustainability is broad and encompasses economic, social and environmental issues (Dyllick \& Hockerts, 2002). This study focuses only on a small part of the larger sustainability field, being corporate response to climate change. Notwithstanding this narrow focus, studies focused on the broader environmental sustainability field provide an initial starting point for the development of a framework. This section highlights the broad sustainability themes identified in previous studies, and determines whether these themes are applicable to climate change mitigation. Finally a proposed conceptual framework is developed.

There is a large body of literature dealing with the relationship between business and the natural environment. Much work has been carried out to understand corporate motivation for engaging with environmental issues. Banerjee (2002) identifies three main themes in corporate sustainability literature which underlie corporate interaction with the natural environment. These themes highlight stakeholder-management linkages, primarily driven by legitimacy concerns; strategic linkages, where the financial business case drives action; and paradigmatic shifts, where moral responsibility considerations are thought to be the dominant motivational factor.

A study conducted by Bansal and Roth (2000) highlights key motivations for ecological responsiveness. The aim of the study was to understand "why companies go green'. The conclusion was that there were three key motivations: competitiveness, legitimation and ecological responsibility. These motivations fall broadly into the same categorisation proposed earlier: i.e. competitiveness tying back to strategic linkages (the financial business case for sustainability); ecological responsibility linked to paradigmatic shifts; and legitimation connected with stakeholder management.

In order to determine whether these themes are relevant from a climate change mitigation perspective, studies focusing on motivations for climate change action were reviewed. Table 1 highlights the findings of a number of international studies which investigate motivations and drivers for corporate climate change strategies. As illustrated in Table 1, the various motivational factors and drivers identified in these studies can be captured in terms of the general themes of broader sustainability studies as proposed by Banerjee (2002) and Bansal and Roth (2000) i.e. legitimacy, the financial business case and moral responsibility.

From a South African perspective very few studies have been conducted in the field of corporate motivations for general sustainability or climate change action. Research regarding climate change responses of companies has been limited to understanding how to facilitate the implementation of the clean development mechanism of the Kyoto Protocol (Little, Maxwell \& Sutherland, 2007) and to studies focussing on the disclosure of climate change responses (KPMG, 2006). 
Table 1

Categorisation of key motivational factors identified in previous surveys and studies in respect of climate change mitigation

\begin{tabular}{|c|c|c|c|c|}
\hline Study/Survey & $\begin{array}{c}\text { Question } \\
\text { addressed by } \\
\text { study/survey }\end{array}$ & Legitimacy & $\begin{array}{c}\text { Financial Business } \\
\text { Case }\end{array}$ & Moral responsibility \\
\hline Hoffman (2005) & $\begin{array}{l}\text { How do } \\
\text { companies believe } \\
\text { they will benefit } \\
\text { from voluntary } \\
\text { GHG reductions? }\end{array}$ & $\begin{array}{l}\text { preparing for } \\
\text { regulation; elevating } \\
\text { corporate reputation }\end{array}$ & $\begin{array}{l}\text { operational } \\
\text { improvement; } \\
\text { accessing new } \\
\text { sources of capital; } \\
\text { improving risk } \\
\text { management; } \\
\text { identifying new market } \\
\text { opportunities; } \\
\text { enhancing human } \\
\text { resource management } \\
\text { (retention of key staff) }\end{array}$ & $\begin{array}{l}\text { enhancing human } \\
\text { resource management } \\
\text { (improve morale) }\end{array}$ \\
\hline Hoffman (2006) & $\begin{array}{l}\text { What motivates } \\
\text { companies to } \\
\text { undertake climate } \\
\text { change action? }\end{array}$ & reputation & cost savings & $\begin{array}{l}\text { social responsibility } \\
\text { (linked to corporate } \\
\text { values) }\end{array}$ \\
\hline Hoffman (2006) & $\begin{array}{l}\text { What are the top } 6 \\
\text { drivers of climate } \\
\text { related strategies? }\end{array}$ & $\begin{array}{l}\text { improving company } \\
\text { reputation among } \\
\text { consumers }\end{array}$ & $\begin{array}{l}\text { desire for increased } \\
\text { operational efficiency; } \\
\text { remaining competitive } \\
\text { with industry peers. }\end{array}$ & $\begin{array}{l}\text { consistency with } \\
\text { existing corporate } \\
\text { culture; protecting the } \\
\text { global climate; social } \\
\text { responsibility }\end{array}$ \\
\hline Hoffman (2006) & $\begin{array}{l}\text { What are the top } \\
6 \text { measures of } \\
\text { success of climate } \\
\text { related strategies? }\end{array}$ & $\begin{array}{l}\text { anticipating and } \\
\text { influencing regulation; } \\
\text { elevating corporate } \\
\text { reputation }\end{array}$ & $\begin{array}{l}\text { energy efficiency; } \\
\text { operational improve- } \\
\text { ment; cost savings }\end{array}$ & $\begin{array}{l}\text { protect the global } \\
\text { climate }\end{array}$ \\
\hline Okereke (2007) & $\begin{array}{l}\text { What are the top } \\
5 \text { motivations for } \\
\text { corporate climate } \\
\text { actions? }\end{array}$ & $\begin{array}{l}\text { credibility and } \\
\text { leverage in climate } \\
\text { policy development; } \\
\text { fiduciary obligations }\end{array}$ & $\begin{array}{l}\text { profit; guiding against } \\
\text { risk }\end{array}$ & ethical considerations \\
\hline Okereke (2007) & $\begin{array}{l}\text { What are the top } \\
5 \text { drivers of } \\
\text { corporate climate } \\
\text { change actions? }\end{array}$ & $\begin{array}{l}\text { regulation and } \\
\text { government directives; } \\
\text { investors pressure }\end{array}$ & $\begin{array}{l}\text { energy prices; market } \\
\text { shifts; technological } \\
\text { change }\end{array}$ & \\
\hline $\begin{array}{l}\text { Bayon, Hawn \& } \\
\text { Hamilton } \\
(2007)\end{array}$ & $\begin{array}{l}\text { What are the top } \\
6 \text { reasons } \\
\text { companies cite for } \\
\text { participating in the } \\
\text { voluntary market? }\end{array}$ & $\begin{array}{l}\text { influence future } \\
\text { regulatory require- } \\
\text { ments and policy } \\
\text { setting; preparing for } \\
\text { potential regulatory } \\
\text { requirements }\end{array}$ & $\begin{array}{l}\text { competitive } \\
\text { differentiation; better } \\
\text { access to capital; } \\
\text { ability to recruit, retain } \\
\text { and reward staff. }\end{array}$ & $\begin{array}{l}\text { inclusion in company- } \\
\text { wide corporate social } \\
\text { responsibility and } \\
\text { sustainability } \\
\text { strategies }\end{array}$ \\
\hline $\begin{array}{l}\text { Hamilton, } \\
\text { Sjardin, } \\
\text { Marcello \& Xu } \\
\text { (2008) }\end{array}$ & $\begin{array}{l}\text { What are the top } \\
3 \text { customer } \\
\text { motivations for } \\
\text { buying offsets? }\end{array}$ & PR/branding & sales of products & $\begin{array}{l}\text { corporate } \\
\text { responsibility }\end{array}$ \\
\hline $\begin{array}{l}\text { McKinsey } \\
(2008)\end{array}$ & $\begin{array}{l}\text { What are the top } \\
5 \text { factors which } \\
\text { influenced } \\
\text { companies to } \\
\text { take climate } \\
\text { change into } \\
\text { consideration? }\end{array}$ & $\begin{array}{l}\text { corporate reputation; } \\
\text { media attention to } \\
\text { climate change; } \\
\text { regulation; consumer } \\
\text { requests or } \\
\text { preferences }\end{array}$ & & $\begin{array}{l}\text { senior executives } \\
\text { personal convictions }\end{array}$ \\
\hline
\end{tabular}

From a broader sustainability perspective, a specialist research panel, comprising twenty professionals from the corporate, academic and NGO fields, identified that South African companies are driven by reputation, issues, and compliance, in respect of sustainable business practice (Trialogue, 2007). Legitimacy concerns seem to drive sustainability action as companies respond reactively to stakeholder concerns. The panellists were of the opinion 
that South Africa lagged its international counterparts when it came to environmental issues. The general view was that responses to environmental issues were still mainly compliance-driven with companies often focussing on economic growth and social development to the detriment of the environment.

Other forces which have been identified as driving South African sustainability responses include fear of litigation, requirements to conform to international standards and efforts to enhance brand and marketing efforts (Bezuidenhout, Fig, Hamann \& Omar, 2007). Once again the key theme would appear to be legitimation and some elements of the financial business case.

No specific studies have been conducted to determine corporate motivations for climate change actions. In recent years the Carbon Disclosure Project (CDP) has included responses from South African companies which provide some insight into motivations for climate change action. The results of the CDP conducted in 2007, which included the top forty South African companies (Tyler, 2008), revealed a high awareness of climate change issues: $89 \%$ of responding companies believed there were business opportunities associated with climate change, with $82 \%$ considering climate change to represent commercial risks. In contrast to this finding, companies have taken very little action in terms of these risks and opportunities, with only $36 \%$ reporting the implementation of emission reduction programmes with targets. There appeared to be very little engagement with government on the issues of climate change, and only $25 \%$ of companies disclosed that they considered the possibility of future emission caps for South Africa.

A year later the CDP survey was extended to cover the top 100 companies in South Africa (Incite Sustainability, 2008). Once again the results revealed a high awareness (87\%) of business opportunities and business risks. While most companies are developing a formal system for measuring and reporting GHG emissions, only $23 \%$ of responding companies have specific emissions-reduction targets in place. A key change in the responses focused on future regulatory intervention. Many companies now believe that the South African government will introduce regulations in the near future. This goes hand in hand with the finding that more companies are now engaging with government, industry bodies and NGOs, in terms of the development of national climate change frameworks and response policies. The CDP surveys seem to indicate that South African corporate response to climate change mirrors its reactive stance in terms of general sustainability issues.

Taking into account the themes and motivational drivers identified in the broader environmental sustainability field, and the reinforcement of these motivational drivers as illustrated in a number of international studies regarding corporate climate change mitigation, the proposed model for this study is illustrated in Figure 1. The proposed conceptual framework highlights the linkages between the three broad concepts of stakeholder management linkages, strategic linkages and paradigmatic shifts which underlie the relationship between business and the natural environment, and the three dominant driving forces of legitimacy, the financial business case and moral responsibility. 


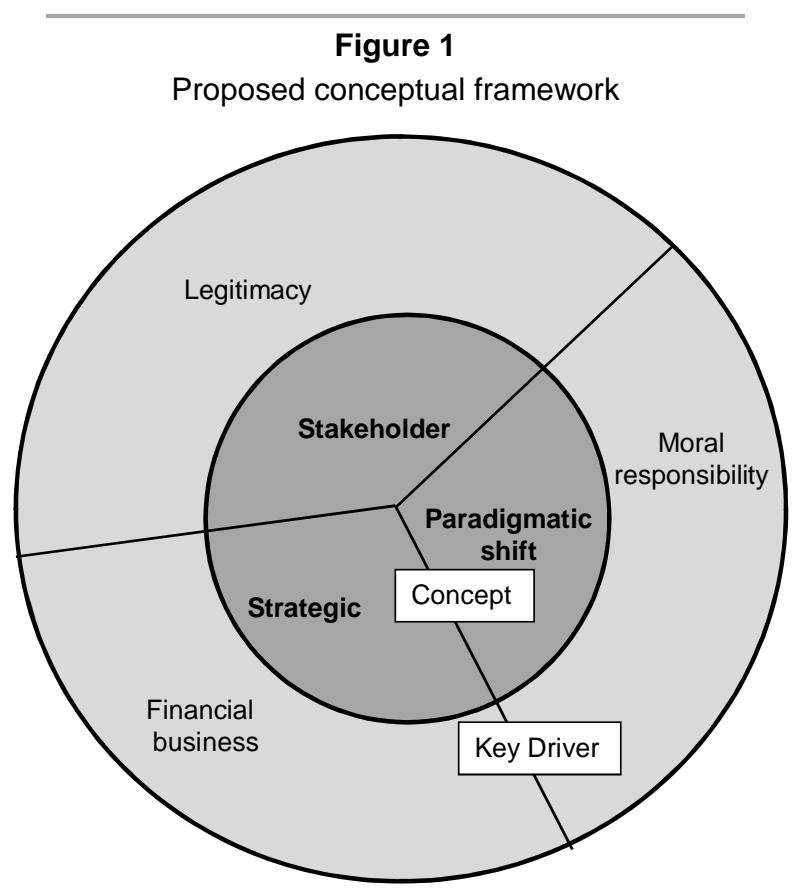

In order to test the validity of the model presented in Figure 1, the empirical phase of this study investigated the response of South African companies to climate change with a view to understanding whether motivational drivers fit into the proposed conceptual framework, or whether there were additional dimensions that need to be included to provide a comprehensive understanding. In addition, the investigation focused on determining whether differences were observed between companies perceived to be sustainability leaders, versus companies perceived to be less accountable and responsible.

\section{3}

\section{Method}

This study sought to understand the motivations for company investment in voluntary climate change action with the objective of developing a comprehensive model of the motivational drivers. Given the lack of information and knowledge regarding key variables, constructs and relationships between variables within the South African context, a qualitative research approach was selected. A case study approach, which allowed for the testing of the proposed conceptual framework in real world situations, was adopted.

\subsection{Selection of case studies}

The study made use of multiple case studies to allow for exploration of both literal and theoretical replication (Yin, 1994). The literal replication logic investigated whether multiple cases fitted into the proposed conceptual framework. In addition, a cross sectional analysis was carried out to determine theoretical replication in terms of which contrasting results were sought from various cases, based on perceptions about the level of accountability or responsibility of each company included in the study.

As the research area was particularly undeveloped from a South African perspective, the intention was to limit the scope of this study from a complexity perspective to allow for initial theory testing. Therefore, the study was limited to three sectors and focused on companies within each sector that were perceived to lead and lag in terms of sustainability. This facilitated an understanding 
of similarities as well as a comparison of differences between companies operating in the same sector and across different sectors. Figure 2 outlines the selection process followed in this study.

Figure 2

Process followed to select cases from overall population

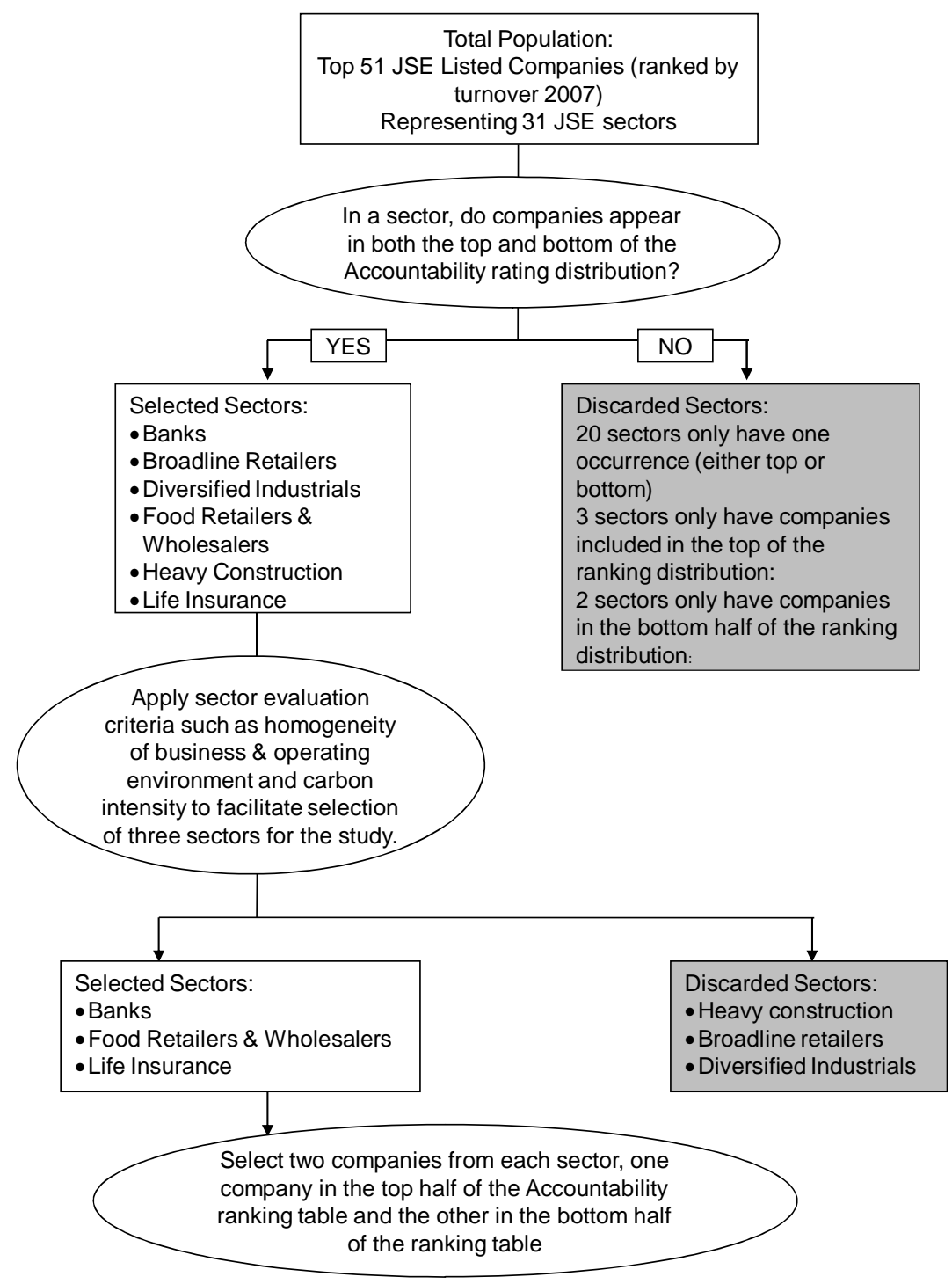

The Accountability Ranking (Accountability, 2007), which provides an external ranking of perceptions of corporate responsibility and accountability of the top 51 companies in South Africa, was used to identify companies perceived to lead and lag in terms of sustainability. To allow comparisons the primary requirement for theoretical replication in this study was that a particular sector needed to have companies in both the top and bottom half of the Accountability rating distribution. This requirement eliminated 25 of the 
31 sectors represented in the Accountability Ranking. As the study was limited to three sectors, a number of factors were included to evaluate which of the remaining six sectors would be included in the study. Key factors taken into consideration were the homogeneity of the business and operating environments of the companies in a particular sector, and the carbon emission intensity of the sectors.

The intention of the final selection process was to ensure that any extraneous variables, which might complicate the comparison between leading and lagging companies in a particular sector and comparisons between sectors, were eliminated. The three sectors selected for the study were: Banks, Food \& Wholesale Retailers and Insurance.

Two companies were selected per sector (one in the top half and one in the bottom half of the Accountability Ranking). Therefore the final case study group consisted of six companies. In order to maintain confidentiality each of the three industries selected in terms of the process outlined above was allocated a specific identifier (A, B or C).Within each sector the company in the top half of the Accountability ranking was categorised as 1 (i.e. A1, B1, C1) and the company in the bottom half of the ranking was categorised as 2 (i.e. A2, B2, C2).

\subsection{Data sources}

The data-collection tools used in the study were interviews and documentary reviews. The individuals responsible for managing sustainability and environmental issues at each of the six selected companies were interviewed in January and February 2009. To facilitate greater co-operation and elicit a truer reflection of company motivations, the respondents were assured that their responses would remain anonymous, and that companies would not be identified by name. With the respondents' consent each interview was taped and later transcribed for use in the data analysis process. The interviews were designed to test corporate motivations for climate change action. They followed a semi-structured approach. The questions were divided into three sections. The first section focussed on the degree of climate change awareness and strategic action of each company. The second section consisted of broad, open-ended questions designed to elicit information on the motivations and drivers for climate change action (or lack of action). Thirdly, open-ended questions were posed to understand the degree to which each of the above-mentioned factors played a role in driving specific actions. ${ }^{1}$

The main sources of supporting documentation were company annual reports, sustainability reports, and company responses to the Carbon Disclosure Project (CDP) (Incite Sustainability, 2008). Annual and sustainability reports available on company websites as at 1 February 2009 were analysed. The Carbon Disclosure Project questionnaire responses for 2008 (CDP 6) were downloaded from the Carbon Disclosure Project website in October 2008.

\subsection{Data analysis}

This study adopted a template analysis process (King, 1998) to generate meaning from the qualitative data. The adoption of the template analysis technique resulted in the use of certain pre-specified categories in the coding process. In addition new categories which emerged from the data analysis process were introduced. The main high-level categories which were pre-specified were the key motivational drivers of legitimacy; the financial business case; and moral responsibility.

To enhance transparency and rigour, computer assisted qualitative data analysis software (CAQDAS), in particular Atlas.ti, which is considered to be one of the leading commercial CAQDAS packages (Lewis, 2004), was used in the analytical process to assist with categorisation and coding of transcribed data. Some of the benefits of using CAQDAS include: enhanced flexibility in terms of coding data; enhanced transparency as a result of the creation of an audit trail of the coding and categorisation process; enhanced validity and rigour arising from a more complete data analysis process; and enhanced analysis arising from network and linkage capabilities of the software which affords the identification of patterns (Kelle, 2004; Kelle \& Laurie, 1995; Lu \& Shulman, 2008; 
Wolfe, Gephart \& Johnson, 1993).

The key element of analysis within the study focused on coding the responses to the interview questions, and coding of supporting documentation. In order to ensure that this was done in a consistent and transparent manner, the case-oriented quantification process proposed by Kuckartz (1995) was employed to combine qualitative and quantitative elements in the analysis of the qualitative data. This involved the analysis of text in the transcribed interviews and supporting documents, and the development of preliminary codes which captured specific elements highlighted in the text related to the motivations for climate change action. Each information source (i.e. interviews, CDP responses, annual reports and sustainability reports) was separately analysed and coded to determine the full range of potential motivating factors. Text segments with the same preliminary codes were analysed to develop themes. Codes relating to the same theme were grouped together in code clusters. The next phase of analysis concentrated on linking the code clusters with the pre-specified categories of the proposed conceptual framework, or developing new categories should the need arise. Further detail regarding the specific code clusters is provided in the results section.

The clustering of codes and allocation to the high-level categories provided the basis for the formation of categories which were then analysed to highlight patterns and themes. To facilitate this process, a level of quantitative translation and analysis assisted in highlighting various dimensions of the cases under review. As the data generated from the coding was categorical in nature, univariate analysis through frequency counts was used to interpret the data. Tests for statistical significance were carried out on the frequency data using the $\mathrm{z}$ test (Lomax, 2001) to make inferences about statistical significance of the differences in frequency proportions per category.

\section{4}

\section{Results}

\subsection{Motivational drivers}

The empirical phase of the study tested whether the motivations for voluntary corporate action in respect of climate change fell into the three categories proposed by the conceptual framework. If not, the model needed to be adapted and extended for unique features of voluntary climate change actions or issues specific to the South African market. In addition, this study tested whether companies, perceived to be more responsible or accountable from a sustainability perspective, displayed differing motivations from companies considered to be less responsible or accountable.

The coding process of both interviews and supporting documents resulted in a total of 670 individual coding instances which in turn linked to 129 preliminary codes. These preliminary codes were reviewed to highlight common themes, which allowed for the division into fourteen code clusters. Decision rules were applied to each code cluster to facilitate final categorisation. The code clusters were ultimately linked to three code categories. Figure 3 illustrates the coding and categorisation process. Table 2 provides a brief description of each cluster and examples of the preliminary codes linked to a particular cluster. In addition Table 2 highlights the decision rules applied in the final categorisation process. 
Figure 3

Overview of code clustering and categorisation

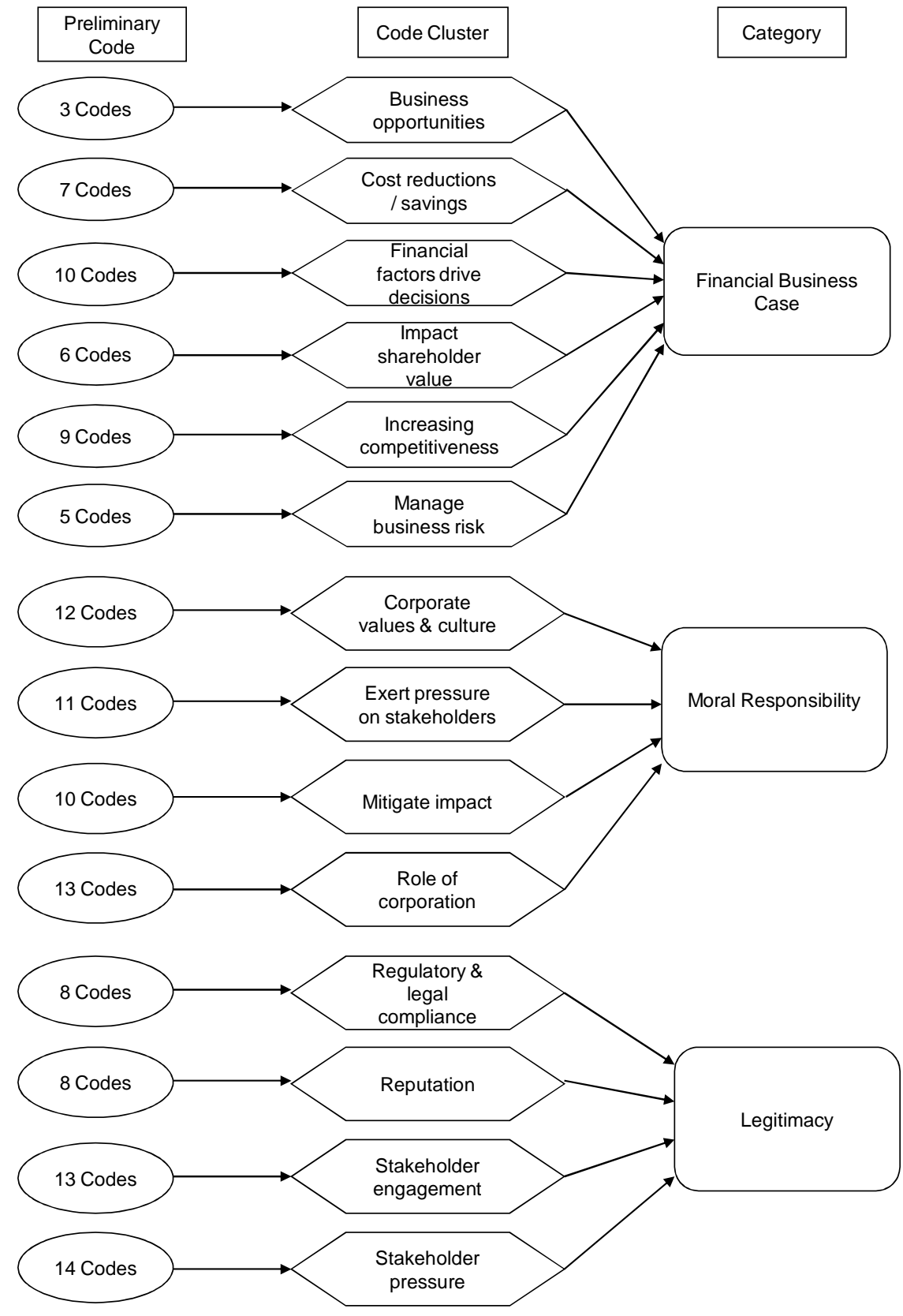


Table 2

Development of code clusters and categories

\begin{tabular}{|c|c|c|c|c|}
\hline $\begin{array}{l}\text { Examples of preliminary } \\
\text { codes }\end{array}$ & Common theme identified & Code Cluster & $\begin{array}{c}\text { Category } \\
\text { Decision Rule }\end{array}$ & Category \\
\hline $\begin{array}{l}\text { Innovation } \\
\text { New green products }\end{array}$ & $\begin{array}{l}\text { Linked to items which provide } \\
\text { evidence of new products / product } \\
\text { innovations / green business } \\
\text { opportunities arising from the } \\
\text { response to environmental / climate } \\
\text { change issues }\end{array}$ & Business opportunities & \multirow{6}{*}{$\begin{array}{l}\text { The actions the } \\
\text { company takes } \\
\text { either make or } \\
\text { save it money. } \\
\text { Decisions are } \\
\text { based on cost } \\
\text { benefit analysis. } \\
\text { Where costs } \\
\text { exceed benefits } \\
\text { the company will } \\
\text { not take action. }\end{array}$} & \multirow{6}{*}{ 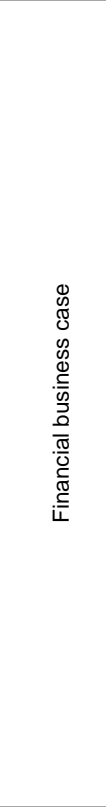 } \\
\hline $\begin{array}{l}\text { Energy efficiency } \\
\text { Fuel cost reductions } \\
\text { Travel cost reductions } \\
\text { Anticipation of increased costs }\end{array}$ & $\begin{array}{l}\text { Environmental initiatives which result } \\
\text { in cost reductions / savings }\end{array}$ & Cost reductions / savings & & \\
\hline $\begin{array}{l}\text { Benefits offset costs } \\
\text { Need to show benefit to } \\
\text { company } \\
\text { Investment not at the expense of } \\
\text { profits } \\
\text { Short-term cost benefit focus }\end{array}$ & $\begin{array}{l}\text { Highlights instances where decisions } \\
\text { regarding investment in } \\
\text { environmental / climate change } \\
\text { mitigation efforts are driven primarily } \\
\text { by financial considerations }\end{array}$ & $\begin{array}{l}\text { Financial factors drive } \\
\text { decisions }\end{array}$ & & \\
\hline $\begin{array}{l}\text { Accessing new sources of } \\
\text { capital } \\
\text { Influence exerted by capital } \\
\text { providers } \\
\text { Goodwill impact } \\
\text { SRI positioning }\end{array}$ & $\begin{array}{l}\text { Actions taken are motivated by the } \\
\text { ultimate impact on shareholder value } \\
\text { as a result of attracting investment or } \\
\text { driving value factors such as goodwill }\end{array}$ & $\begin{array}{l}\text { Impact on shareholder } \\
\text { value }\end{array}$ & & \\
\hline $\begin{array}{l}\text { Competitive differentiation } \\
\text { Brand positioning } \\
\text { Leadership position } \\
\text { Competitive advantage }\end{array}$ & $\begin{array}{l}\text { Evidence of the company using } \\
\text { leadership position on environmental } \\
\text { issues to increase its competitive } \\
\text { positioning }\end{array}$ & $\begin{array}{l}\text { Increasing } \\
\text { competitiveness }\end{array}$ & & \\
\hline $\begin{array}{l}\text { Manage supply chain risk } \\
\text { Manage customer risk profiles } \\
\text { Manage future risk impact }\end{array}$ & $\begin{array}{l}\text { Evidence of the company taking } \\
\text { action in respect of environmental } \\
\text { issues to mitigate business risk }\end{array}$ & Managing business risk & & \\
\hline $\begin{array}{l}\text { Management commitment } \\
\text { Environment explicitly part of } \\
\text { company strategy } \\
\text { Lead by example } \\
\text { Inclusion of environmental } \\
\text { targets in management } \\
\text { scorecards }\end{array}$ & $\begin{array}{l}\text { Aspects which highlight elements of } \\
\text { corporate values and culture which } \\
\text { are supportive of environmental } \\
\text { issues. This would include the } \\
\text { demonstration of top management } \\
\text { commitment and inclusion of } \\
\text { environmental issues in the } \\
\text { company's main business strategy }\end{array}$ & $\begin{array}{l}\text { Corporate values and } \\
\text { culture }\end{array}$ & \multirow{4}{*}{$\begin{array}{l}\text { It costs the } \\
\text { company money } \\
\text { or time to take } \\
\text { action but the } \\
\text { company regards } \\
\text { it as the right } \\
\text { thing to do. }\end{array}$} & \multirow{4}{*}{ 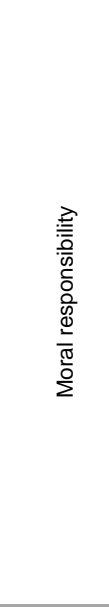 } \\
\hline $\begin{array}{l}\text { Encourage behaviour change in } \\
\text { customers } \\
\text { Drive environmental awareness } \\
\text { Exert pressure on supply chain }\end{array}$ & $\begin{array}{l}\text { Evidence of the company pressuring } \\
\text { stakeholders to act on environmental/ } \\
\text { climate change issues and driving } \\
\text { behaviour changes. }\end{array}$ & $\begin{array}{l}\text { Exert pressure on } \\
\text { stakeholders }\end{array}$ & & \\
\hline $\begin{array}{l}\text { Reduce, reuse, recycle } \\
\text { Develop and support green } \\
\text { technology } \\
\text { Offset particular events }\end{array}$ & $\begin{array}{l}\text { Company actions are driven by } \\
\text { attempts to mitigate environmental } \\
\text { impact, with little or no economic } \\
\text { benefit to the company }\end{array}$ & Mitigate impact & & \\
\hline $\begin{array}{l}\text { Best practice environmental } \\
\text { management policies } \\
\text { Conserve environment for future } \\
\text { generations } \\
\text { Corporate social and } \\
\text { environmental investment }\end{array}$ & $\begin{array}{l}\text { Evidence and examples of the } \\
\text { company playing a role as a result of } \\
\text { corporate social and environmental } \\
\text { responsibility }\end{array}$ & $\begin{array}{l}\text { Role of the corporation in } \\
\text { terms of social and } \\
\text { environmental } \\
\text { responsibility }\end{array}$ & & \\
\hline $\begin{array}{l}\text { Leadership role in policy } \\
\text { formulation } \\
\text { Engage with regulators } \\
\text { Act in anticipation of regulation }\end{array}$ & $\begin{array}{l}\text { Company action driven by current or } \\
\text { anticipated legislation and regulatory } \\
\text { pressure }\end{array}$ & $\begin{array}{l}\text { Regulatory and legal } \\
\text { compliance }\end{array}$ & \multirow{4}{*}{$\begin{array}{l}\text { The company } \\
\text { takes action } \\
\text { because } \\
\text { stakeholders } \\
\text { expect, or will } \\
\text { soon expect it to } \\
\text { take action }\end{array}$} & \multirow{4}{*}{ 己े } \\
\hline $\begin{array}{l}\text { Protect corporate reputation } \\
\text { Build reputation } \\
\text { Increase credibility }\end{array}$ & $\begin{array}{l}\text { Evidence of company taking action to } \\
\text { protect or build its reputation }\end{array}$ & Reputation & & \\
\hline $\begin{array}{l}\text { Attract and retain customers } \\
\text { Staff engagement } \\
\text { Community engagement }\end{array}$ & $\begin{array}{l}\text { Evidence of proactive engagement } \\
\text { with stakeholder groups to manage } \\
\text { environmental expectations }\end{array}$ & Stakeholder engagement & & \\
\hline $\begin{array}{l}\text { Consumer pressure } \\
\text { Pressure from supply chain } \\
\text { Pressure from investors }\end{array}$ & $\begin{array}{l}\text { Evidence of the company reacting to } \\
\text { stakeholder pressure in respect of } \\
\text { environmental expectations }\end{array}$ & Stakeholder pressure & & \\
\hline
\end{tabular}


Table 3 provides an overview of the code counts per cluster and category. As illustrated in Table 3, all of the data sources contained codes related to the 14 cluster categories. The code categories were observed in the data from each sector. This illustrated the broader applicability of the model providing evidence that from a literal replication perspective, the proposed conceptual model incorporated motivational drivers relevant to multiple industries. This appears to support the use of the proposed conceptual framework to classify motivational factors for voluntary action to mitigate climate change.

Table 3

Code counts per data source per code cluster

\begin{tabular}{|c|c|c|c|c|c|c|c|c|c|c|}
\hline \multicolumn{2}{|c|}{ Data source } & \multirow{2}{*}{\multicolumn{3}{|c|}{$\begin{array}{c}\text { Interview transcripts } \\
\text { Sector }\end{array}$}} & \multirow{2}{*}{\multicolumn{3}{|c|}{$\begin{array}{l}\text { CDP } \\
\text { Sector }\end{array}$}} & \multirow{2}{*}{\multicolumn{3}{|c|}{$\begin{array}{c}\text { Annual \& } \\
\text { sustainability report } \\
\text { Sector }\end{array}$}} \\
\hline \multirow{2}{*}{$\begin{array}{l}\text { Code } \\
\text { category }\end{array}$} & \multirow{2}{*}{ Code cluster } & & & & & & & & & \\
\hline & & A & B & C & A & B & C & A & B & C \\
\hline \multirow{7}{*}{ 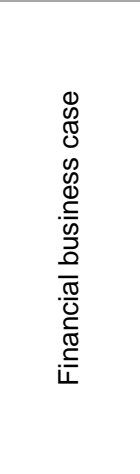 } & Cost reductions & 12 & 11 & 9 & 11 & 16 & 10 & 8 & 18 & 6 \\
\hline & $\begin{array}{l}\text { Financial factors } \\
\text { drive decisions }\end{array}$ & 9 & 4 & 11 & 1 & - & 1 & - & 1 & - \\
\hline & $\begin{array}{l}\text { Increasing } \\
\text { competitiveness }\end{array}$ & 6 & 9 & 2 & 4 & 4 & 3 & -- & 6 & 1 \\
\hline & $\begin{array}{l}\text { Impact on } \\
\text { shareholder value }\end{array}$ & 1 & 3 & 2 & - & 1 & 1 & - & 4 & 4 \\
\hline & $\begin{array}{l}\text { Managing } \\
\text { business risk }\end{array}$ & 7 & 8 & - & 6 & 10 & 6 & 4 & 7 & 3 \\
\hline & $\begin{array}{l}\text { Business } \\
\text { opportunities }\end{array}$ & 2 & 1 & - & 7 & 14 & 2 & 2 & 5 & - \\
\hline & SUBTOTAL & 37 & 36 & 24 & 29 & 45 & 23 & 14 & 41 & 14 \\
\hline \multirow{5}{*}{ 勇 } & $\begin{array}{l}\text { Regulatory and } \\
\text { legal compliance }\end{array}$ & 1 & 5 & 1 & 5 & 12 & 5 & 2 & 4 & 1 \\
\hline & Reputation & 2 & 6 & 6 & - & 7 & 3 & 3 & 14 & 5 \\
\hline & $\begin{array}{l}\text { Stakeholder } \\
\text { engagement }\end{array}$ & 9 & 12 & 6 & 9 & 10 & 7 & 4 & 10 & 7 \\
\hline & $\begin{array}{l}\text { Stakeholder } \\
\text { pressure }\end{array}$ & 11 & 7 & 4 & 2 & 1 & - & 2 & 4 & - \\
\hline & SUBTOTAL & 23 & 30 & 17 & 16 & 30 & 15 & 11 & 32 & 13 \\
\hline \multirow{5}{*}{ 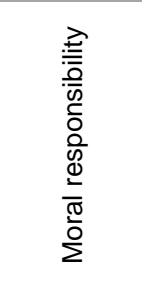 } & Role of corporation & 9 & 8 & 8 & - & 4 & 5 & 3 & 11 & 6 \\
\hline & Mitigate impact & 9 & 8 & 4 & 7 & 4 & 3 & 9 & 7 & 3 \\
\hline & $\begin{array}{l}\text { Corporate values } \\
\text { and culture }\end{array}$ & 3 & 8 & 3 & 4 & 8 & 3 & 3 & 4 & 5 \\
\hline & $\begin{array}{l}\text { Exert pressure on } \\
\text { stakeholders }\end{array}$ & 8 & 3 & 1 & 12 & 7 & 7 & 5 & 16 & 12 \\
\hline & SUBTOTAL & 29 & 27 & 16 & 23 & 23 & 18 & 20 & 38 & 26 \\
\hline \multicolumn{2}{|l|}{ TOTAL } & 89 & 93 & 57 & 68 & 98 & 56 & 45 & 111 & 53 \\
\hline
\end{tabular}

This study found that all the motivational factors driving voluntary climate change action in the six South African companies reviewed could be categorised in terms of the three key driver categories of the proposed conceptual framework. In addition, the study revealed a number of clusters associated with each key driver which contained additional information regarding company motivations.

When considering the results of the theoretical replication aspect of this study, the focus shifted to identifying whether differences were observed between particular companies within each sector. From the perspective of 
motivational drivers, the main difference observed between top ranked companies (A1, $\mathrm{B} 1$ and $\mathrm{C} 1$ ) and the lower ranked companies (A2, B2 and C2) was not necessarily observed at a code category level. No statistically significant differences were observed between the frequency of occurrence of codes in support of each category for companies in each sector. Rather the differences were observed in the particular strategies and the specific code clusters emphasised by each company in the interviews and supporting documents.
The data analysis of code cluster differences focussed on identifying which company in each sector highlighted particular clusters with a greater frequency than its sector counterpart. Table 4 provides details of which company per sector scored a higher frequency proportion per cluster. The difference is considered to be statistically significant at the $90 \%$ confidence interval. This analysis facilitates a comparison of companies which lead and lag in terms of sustainability within each sector.

Table 4

Statistically significant differences in cluster frequency proportions per sector

\begin{tabular}{|c|c|c|c|c|}
\hline \multirow[b]{2}{*}{ Category } & \multirow[b]{2}{*}{ Code cluster } & \multicolumn{3}{|c|}{$\begin{array}{c}\text { Company per sector with highest frequency score } \\
\text { (statistically significant difference from sector } \\
\text { counterpart at } 90 \% \text { confidence level, i.e. } p<=0.1 \text { ) } \\
\text { (z-test values in brackets) }\end{array}$} \\
\hline & & Interview & CDP & $\begin{array}{c}\text { Annual \& } \\
\text { sustainability } \\
\text { report }\end{array}$ \\
\hline \multirow{6}{*}{ 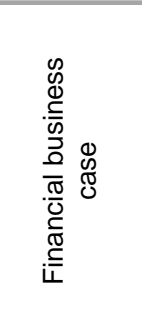 } & Cost reductions & & B2 (1.83) & \\
\hline & Financial factors drive decisions & & & \\
\hline & Increasing competitiveness & $\begin{array}{l}\text { A1 (1.95) } \\
\text { B1 (2.18) }\end{array}$ & B1 (2.85) & \\
\hline & Impact on shareholder value & & & $\mathrm{B} 1(1.28)$ \\
\hline & Managing business risk & $\mathrm{A} 1(2.11)$ & C2 (1.98) & B2 (1.62) \\
\hline & Business opportunities & & $\begin{array}{l}\text { C2 (2.14) } \\
\text { B1 (1.70) }\end{array}$ & B1 (1.67) \\
\hline \multirow{4}{*}{ 兽 } & Regulatory and legal compliance & & B2 (1.37) & \\
\hline & Reputation & $\begin{array}{l}\text { A2 (1.85) } \\
\text { C2 (1.43) }\end{array}$ & & C2 (1.64) \\
\hline & Stakeholder engagement & $\begin{array}{l}\text { A1 (2.42) } \\
\text { C1 (2.04) }\end{array}$ & & \\
\hline & Stakeholder pressure & B2 (1.41) & & B2 (1.80) \\
\hline \multirow{4}{*}{ 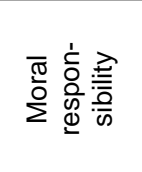 } & Role of corporation & B1 (1.96) & & $\mathrm{B} 1(1.40)$ \\
\hline & Mitigate impact & C1 (1.65) & & B2 (2.41) \\
\hline & Corporate values and culture & B1 (1.96) & C2 (1.36) & B1 (2.31) \\
\hline & Exert pressure on stakeholders & & B1 (1.60) & \\
\hline
\end{tabular}

The key differentiating factors observed between companies that lead and lag in terms of sustainability are present at a general climate change strategy level. The code clusters emphasised by companies in the interviews and supporting documents provide insights into the factors motivating the adoption of particular strategies. From a climate change strategy approach, all top ranked companies had adopted climate change mitigation strategies and had set targets for emission reductions. Two of the three companies (A1 and B1) stated the intention of taking a leadership role in climate change mitigation in their sector. The third company, $\mathrm{C} 1$, while not adopting a leadership position in respect of climate change specifically, was focussed on positioning itself as a socially responsible investment with the required focus on environmental and climate change issues 
that such positioning requires.

Two of the top ranked companies (A1 and B1) displayed proactive strategies in terms of increasing competitiveness and resultant brand positioning. A recurrent theme highlighted by company A1's respondent was the focus on the company brand and the resultant brand positioning, as the following quote reveals: 'From a brand point of view it's the kind of thing that our brand gets involved in ... we care about environmental issues'. Company B1's respondent focused on competitive positioning, pointing out that 'people will actually come to us because they know we are supportive of corporate social investment, and specifically green issues.' Both company A1 and C1 proactively engaged with stakeholders regarding climate change mitigation. Company $\mathrm{C} 1$ had a strong focus on mitigating its impact, and had set targets for switching to renewable energy sources. Company B1 highlighted strong corporate values in support of environmental responsibility and a proactive stance in terms of exerting pressure on stakeholders.

The lower ranked companies displayed varying levels of commitment to adopting climate change strategies, ranging from no strategy (in the case of A2) to a strategy that was under development (company B2) to a strategy in place but with no targets set for emissions reduction (company $\mathrm{C} 2$ ). The reactive nature of the response of these companies was further emphasised by little evidence of companies using climate change as an opportunity to increase competitiveness or engage with stakeholders. Company B2's respondent stated that: 'the major objective is not necessarily to get a lot of marketing out of it' while Company A2's respondent noted that 'we are not necessarily going to go out there and position ourselves as the green company.'
Instead concerns centred on protecting corporate reputation (company A2 and $\mathrm{C} 2$ ) and in the case of company $\mathrm{A} 2$ and $\mathrm{B} 2$, reacting to stakeholder pressure. Company C2's respondent pointed out that from a reputational point of view, 'if it gets out that (our company) doesn't care about the environment, it is an emotive issue.' Company B2's respondent highlighted that '(the company) is forced to pick up on whatever they (the external stakeholders) are doing (from a climate change perspective).' In addition, company B2's respondent pointed out on a number of occasions that climate change was first and foremost considered a risk by the company.

Therefore, the major aspect that appears to differentiate top ranked and lower ranked companies in this particular study is the proactive stance adopted by top ranked companies as opposed to the reactive, reputation driven, and in some cases, risk mitigation approach adopted by lower ranked companies. The differences observed are at a code cluster rather than a code category level. This has important implications for using the proposed conceptual model to assist in understanding corporate sustainability motivational drivers. In particular, comparisons of companies at a key driver level (related to code categories) will not necessarily provide the depth of insight required to determine the true factors driving company action in terms of climate change.

\subsection{Extension of conceptual framework}

In light of the above findings, the conceptual framework is extended to provide for the particular code cluster categories as highlighted in the analysis of the case studies. The resultant framework is depicted in Figure 4. 


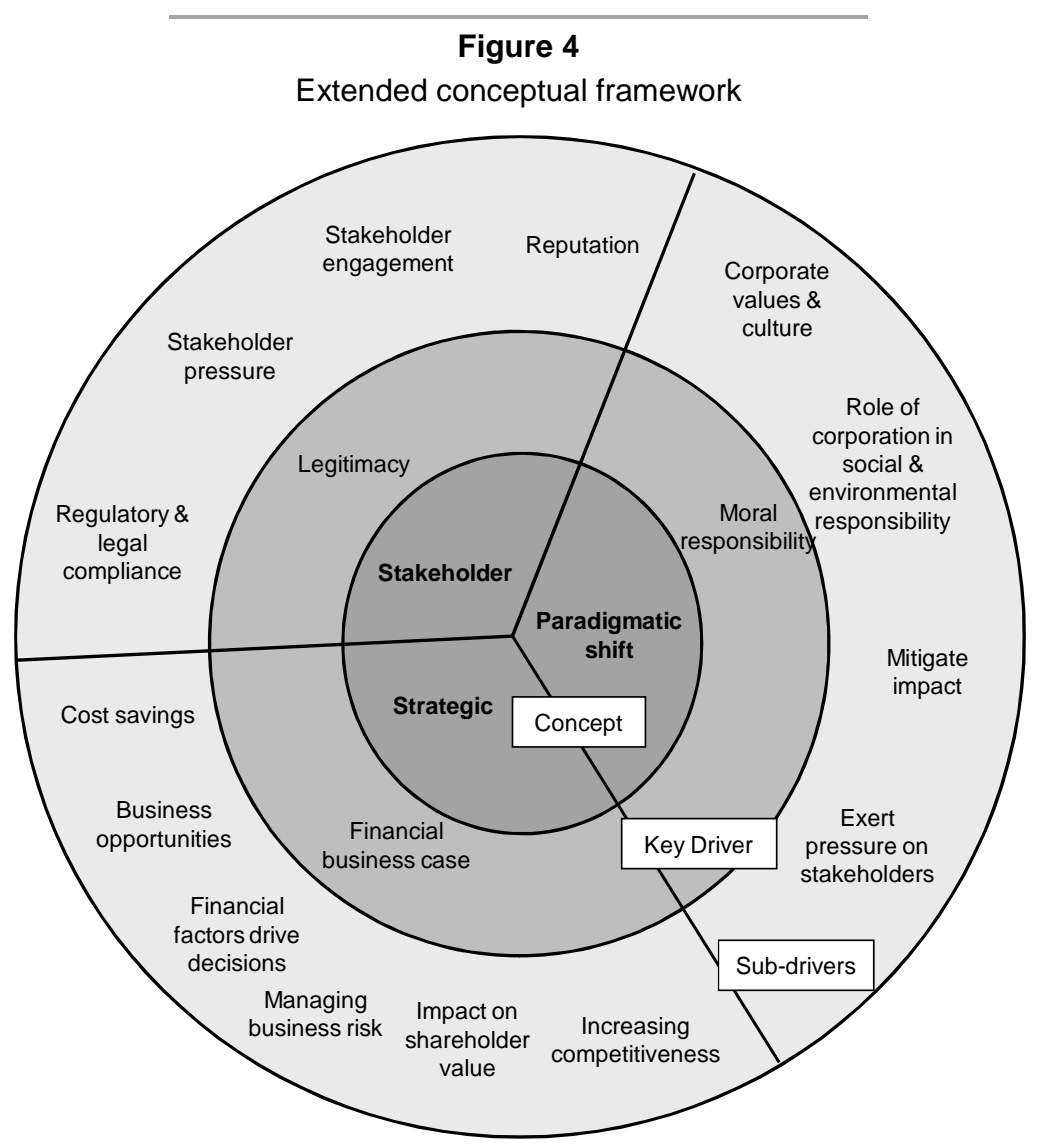

Figure 4 highlights the linkages between the three core concepts which explain the interaction of business with the natural environment, and the resultant key drivers supporting each concept. A third level of information is added to this model to incorporate the existence of sub-drivers arising out of the code cluster categories. These subdrivers link to particular key drivers and provide vital information which allows distinctions to be drawn between the motivations of different companies.

The empirical process followed in this study has therefore enabled the transition from a proposed model to a preliminary conceptual model. The model outlines the interaction between the company and the natural environment and highlights the key motivational drivers and sub-drivers of corporate climate change mitigation.

\section{5}

\section{Discussion}

The purpose of this study was to understand why companies invest in voluntary climate change initiatives. Two key areas were examined. The first was to investigate the motivations for voluntary climate change action and the second was to determine whether differences in motivations were observed between companies perceived to be more responsible and less responsible from a sustainability perspective.

When considering what motivates companies to take voluntary action in respect of sustainability issues, the literature review revealed three main concepts underlying the business interaction with the natural environment. These were stakeholder concerns, strategic linkages and paradigmatic shifts. The main drivers supporting each 
concept were legitimacy concerns, the financial business case and moral responsibility.

The empirical study confirmed that these concepts and drivers explained the motivations for voluntary climate change action within the six companies studied. Therefore the study found that the proposed conceptual framework encompassed the various motivational drivers identified in terms of voluntary climate change action of the selected companies.

In addition, the empirical study highlighted that specific sub-drivers provided further information regarding company motivations. This information differentiated between companies perceived to be more responsible and accountable from a sustainability perspective, and those perceived to be less responsible. The sub-drivers which motivated sustainability leaders in each of the three sectors appeared to focus on proactive elements, while those motivating the lower ranked companies focused on reactive strategies.

\section{6}

\section{Conclusion}

This study has facilitated a preliminary understanding of the factors motivating South African companies to take action in respect of climate change mitigation. The resultant framework outlined in Figure 4 highlights the three primary drivers which focus on moral responsibility, legitimacy and the financial business case. Each of these three drivers is in turn the product of a number of sub-drivers which facilitate a greater understanding of the different issues which drive companies to take action. Those that are perceived to be more accountable and responsible appear to adopt a proactive strategy, and those companies perceived to be less accountable and responsible appear to have a reactive strategy. This study suggests that engagement with proactive companies should focus on emphasising brand and competitive positioning benefits. Reactive companies would respond to reputational, regulatory and risk signals.

A key limitation of the study is that only six companies were analysed. In addition, the selection process adopted in this study resulted in the inclusion of companies in industries considered to have low direct impact from a climate change perspective. The results of this study might differ for higher direct-impact companies who may have different motivational factors. Investigating these differences falls outside the scope of this study and is an area requiring further research.

While the exploratory nature of this study necessitated a narrow focus on six companies in three industries, further research could be carried out on a larger portion of the South African corporate market to ascertain whether motivational factors continue to be explained by the three themes identified. Once validated in this broader South African corporate context, the framework could assist in developing solutions to the threat of climate change.

As South Africa moves towards the publication of a national response to climate change, the motivations identified in the study provide insights which can be used by various parties to assist in engaging corporate South Africa in the development of the country's response to the threat of climate change. This includes parties engaged in developing voluntary carbon-offset projects, parties engaged in the development of policies and procedures related to voluntary climate change action, and parties developing regulations to direct corporate response to climate change.

\section{Acknowledgements}

The authors would like to thank the two anonymous reviewers for their helpful comments on the article.

\section{Endnote}

1 A copy of the interview questionnaire is available from the corresponding author. 


\section{References}

ACCOUNTABILITY. 2007. Accountability rating 2007. [Online] Available from: http://www.unisa.ac.za/contents/colleges/col_econ_man_science/ccc/docs/Accountability\%20Rating\%20200 7\%20Report.pdf [Accessed: 2008-3-27].

BANERJEE, S.B. 2002. Corporate environmentalism: The construct and its measurement. Journal of Business Research, 55:177-191.

BANSAL, P. \& ROTH, K. 2000. Why companies go green: A model of ecological responsiveness. The Academy of Management Journal, 43(4):717-736.

BAUMERT, K.A., HERZOG, T. \& PERSHING, J. 2005. Navigating the numbers: greenhouse gas data and international climate policy. World Resources Institute. [Online] Available from: http://www.wri.org/publication/navigating-the-numbers [Accessed: 2009-06-01].

BAYON, R., HAWN, A. \& HAMILTON, K. 2007. Voluntary carbon markets: An international business guide to what they are and how they work. London: Earthscan.

BEZUIDENHOUT, A., FIG, D., HAMANN, R. \& OMAR, R. 2007. Political Economy. In: Fig, D. (ed.) Staking their claims: corporate social and environmental responsibility in South Africa. Scottsville: University of KwaZulu-Natal Press.

BLIGNAUT, J.N., MABUGU, R.M. \& CHITIGA-MABUGU, M.R. 2005. Constructing a greenhouse gas emissions inventory using energy balances: the case of South Africa: 1998. Journal of Energy in Southern Africa, 16(3):105-116.

BOKO, M., NIANG, I., NYONG, A., VOGEL, C., GITHEKO, A., MEDANY, M., OSMAN-ELASHA, B., TABO, R. \& YANDA, P. 2007. AFRICA. IN: PARRY, M.L., CANZIANI, O.F., PALUTIKOF, J.P., VAN DER LINDEN, P.J. \& HANSON, C.E. (eds.) Climate change 2007: Impacts, adaptation and vulnerability. contribution of working group II to the fourth assessment report of the intergovernmental panel on climate change. Cambridge, UK: Cambridge University Press. [Online] Available from: http://www.ipcc.ch/publications_and_data/ar4/wg2/en/ch9.html [Accessed: 2009-05-22].

DEPARTMENT OF ENVIRONMENTAL AFFAIRS AND TOURISM, 2009. National climate change response policy: discussion document for the 2009 national climate change response policy development summit. [Online] Available from: www.ccsummit2009.co.za/framework.html [Accessed: 2009-05-22].

DYLLICK, T. \& HOCKERTS, K. 2002. Beyond the business case for corporate sustainability. Business Strategy and the Environment, 11(2):130-141.

GROBBELAAR, N. 2008. South African corporate engagement with Africa: experiences, lessons and policy recommendations. In: Grobbelaar, N. \& Besada, H. Unlocking Africa's potential: the role of corporate South Africa in strengthening Africa's private sector. Johannesburg, South Africa: SAIIA.

HAMILTON, K., SJARDIN, M., MARCELLO, T. \& XU, G. 2008. Forging a frontier: State of the voluntary carbon markets 2008. Ecosystem Marketplace \& New Carbon Finance. [Online] Available from: http://www.newcarbonfinance.com /?p=reports [Downloaded: 2008-05-12].

HOFFMAN, A.J. 2005. Climate change strategy: The business logic behind voluntary greenhouse gas reductions. California Management Review, 47(3): 21-46.

HOFFMAN, A.J. 2006. Getting ahead of the curve: Corporate strategies that address climate change. Pew Center on Global Climate Change. [Online] Available from: http://www.pewclimate.org/global-warming-indepth/all_reports/ corporate_strategies [Accessed: 2008-02-07].

INCITE SUSTAINABILITY. 2008. Carbon disclosure project report 2008: JSE Top 100. [Online] Available from: http://www.cdproject.net/reports.asp [Accessed: 2008-11-20].

KELLE, U. 2004. Computer-assisted qualitative data analysis. In Seale, C., Gobo, G., Gubrium, J.F. \& Silverman, D. (eds.) Qualitative research practice. London: Sage Publications.

KELLE, U. \& LAURIE, H. 1995. Computer use in qualitative research and issues of validity. In Kelle, U. (ed.) Computer-aided qualitative data analysis: theory, methods and practice. London: Sage Publications. KING, N. 1998. Template analysis. In: Symon, G. \& Cassell, C. (eds.) Qualitative methods and analysis of organizational research: a practical guide. London: Sage Publications.

KPMG. 2006. 2006 survey of integrated sustainability reporting in South Africa. [Online] Available from: http://www.kpmg.co.za/images/naledi /pdf\%20documents/mc1672\%20sustainability\%20survey\%2036pg.pdf [Accessed: 2008-03-28]. 
KUCKARTZ, U. 1995. Case-oriented quantification. In Kelle, U. (ed.) Computer-aided qualitative data analysis: theory, methods and practice. London: Sage Publications.

LEWIS, R.B. 2004. NVivo 2.0 and ATLAS.ti 5.0: A comparative review of two popular qualitative dataanalysis programs. Field Methods, 16(4):439-469.

LITTLE, G., MAXWELL, T. \& SUTHERLAND, M. 2007. Accelerating the implementation of the clean development mechanism in South Africa. South African Journal of Economic and Management Sciences, 10(4):395-411.

LOMAX, R.G. 2001. An introduction to statistical concepts for education and behavioural sciences. New Jersey: Lawrence Erlbaum Associates.

LU, C. \& SHULMAN, S.W. 2008. Rigor and flexibility in computer-based qualitative research: introducing the Coding Analysis Toolkit. International Journal of Multiple Research Approaches, 2(1):105-117.

MCKINSEY. 2008. How companies think about climate change: a McKinsey global survey. McKinsey \& Company. [Online] Available from: http://www.mckinseyquarterly.com/How_companies_think_about_ climate_change_A_McKinsey_Global_Survey_2099 [Accessed: 2008-07-18].

OKEREKE, C. 2007. An exploration of motivations, drivers and barriers to carbon management: The UK FTSE 100, European Management Journal, 25(6):475-486.

SCENARIO BUILDING TEAM. 2007. Long term mitigation scenarios: strategic options for South Africa. Pretoria: Department of Environment Affairs and Tourism. [Online] Available from: http://www.environment.gov.za/HotIssues /2008/LTMS/LTMS.html [Accessed: 2009-06-08].

TRIALOGUE. 2007. The sustainable business handbook: smart strategies for responsible companies $\left(4^{\text {th }}\right.$ ed.) Cape Town: Trialogue.

TYLER, E. 2008. Carbon disclosure project South Africa report 2007: JSE Top 40. [Online] Available from: http://www.cdproject.net/cdp5reports.asp [Accessed: 2008-03-27].

VAN HEERDEN, J.H., GERLAGH, R., BLIGNAUT, J.N., HESS, S., MABUGU, R., CHITIGA, M., \& DE WET, T. 2006. Searching for triple dividends in South Africa: fighting $\mathrm{CO}_{2}$ and poverty while promoting growth. The Energy Journal, 27(2):113-141.

WATKINS, K. 2007. Human Development Report 2007/2008: Fighting climate change: Human solidarity in a divided world. New York: UNDP.

WOLFE R.A., GEPHART R.P. \& JOHNSON T.E. 1993. Computer-facilitated qualitative data analysis: potential contributions to management research. Journal of Management, 19(3):637-660.

YIN, R.K. 1994. Case study research: design and methods. (2 ${ }^{\text {nd }}$ ed.) California: Sage Publications. 